\title{
The character and significance of migration traditions from Finland to North America
}

By

Reino Kero

University of Turku

In some areas of Finland emigration was intense over several decades, but the objective of migrations from other certain areas might have been some particular city in the homeland. An intense emigration to transatlantic countries was part of the migration traditions of Vaasa province, while in the provinces of eastern and southern Finland, this tradition was very weak and short-lived. We can thus say that the migration traditions of Vaasa province were very different from those of eastern and southern Finland. ${ }^{1}$

Most communes in Vaasa province had an intense emigration tradition to transatlantic countries, but the streams of emigrants coming from these communes are found to be remarkably different if the destinations of the streams are compared. Similar results can be found if the weaker emigration streams from other provinces are studied. A few particularly distinctly observable traditions are given below as examples.

In $1882,{ }^{2} 48$ emigrants departed for transatlantic countries from the neighbouring communes of Ylistaro and Isokyro. Of these, 24 $(50.0 \%)$ had purchased tickets to Ohio. In 1890, 81 emigrants departed, $10(12.3 \%)$ of whom went to Ohio, and of 365 emigrants leaving in $1905,88(24.1 \%)$ were destined for Ohio. Only 5.3\%, $2.5 \%$ and $3.4 \%$ of the total Finnish emigration during these years was directed to Ohio.

Emigration from Finland to Utah came from a comparatively small region in the vicinity of Vaasa. Already in 1882, 16 emigrants left this area for Utah. In 1890, 20 left for Utah and 80 in 1905. Of the area's total emigration, the portion going to Utah during 
these years was $4.7 \%, 3.0 \%$ and $6.8 \%$ and those of Finland's total emigration only $1.0 \%, 1.2 \%$ and $0.7 \%$.

Emigration from southwest Finland was distinctly directed to New York. In 1890, of the 108 emigrants leaving this area, 46 (42.6\%) had purchased tickets to New York. Of the 953 leaving in 1905,424 or $44.5 \%$ had purchased tickets lor New York. According to passenger lists, $27.2 \%$ and $14.6 \%$ of the total Finnish emigration was directed to New York during these years. ${ }^{3}$

Finnish emigration to Canada originated, at least before World War I, mainly from the southern parts of Vaasa province and a few communes from its southeastern parts. Emigration to Canada may have begun from this area earlier than anywhere else in Finland. In 1890, from the seven communes belonging to the core area of emigration to Canada, $10(6.1 \%)$ emigrants of a total of 164 had purchased tickets to Ontario. Only $1.0 \%$ of the country's total emigration during this year was directed to Ontario. In 1905, of the area's 1079 emigrants 191 or $17.7 \%$ went to Ontario. In addition, one emigrant purchased a ticket to British Columbia and one to Manitoba. Of Finland's total emigration in 1905, 5.1\% (947 emigrants) was directed to Ontario. ${ }^{4}$

Of 14 emigrants in 1882 from Rantsila in Oulu province, 9 $(64.3 \%)$ had purchased tickets to Michigan. In 1890, 9 (42.9\%) of 21 emigrants leaving this commune went to Michigan, and in 1905, $23(52.3 \%)$ of 44 emigrated to Michigan.

\section{The birth of emigration traditions}

How were migration traditions born? There were two basic conditions necessary for the birth of a migration tradition. On the one hand, there had to be some kind of continual migration pressure in the areas of departure of emigrants. This kind of factor may have been, for example, the poor employment opportunities in the departure area. The second condition was the nearly free, good agricultural farming land offered at the areas of destination in North America during the early stages of emigration, and perhaps even in the 1880's. In later stages, the most important factor might have been the demand for labour which arose from time to time and the comparatively higher level of income available in the destination areas than in Europe. However, for the first emigrant from a certain district it was not enough that he knew that agricultural farming Iand could be obtained almost for nothing in North America or that 
higher wages were paid in America than in Europe. He had also to know exactly where he was going and how he could get there. It is therefore important to know how the first emigrants obtained the information on which they based their decision to leave.

In the early days of emigration from Finland in the 1870 's, a few so-called emigrant recruiters travelled around in northern Finland. It would appear that their main aim was to obtain labour for the mines of northern Michigan, which to some extent they succeeded in doing. ${ }^{5}$ The important position of Michigan as the destination area of Finnish emigration was probably partly due to this recruitment activity. Another case in which recruitment probably created a strong migration tradition that lasted for several decades was in the Kristiinankaupunki area where leaflets containing information on Canada were distributed in the early 1880's. It was from this area that emigration from Finland to Canada began and for at least thirty years the Kristiinankaupunki-Isojoki-Kauhajoki-KarijokiKarvia region was the core area of Finnish emigration to Canada. ${ }^{6}$

Recruitment activity of course did not necessarily create a tradition. It may have remained totally without results, as with Hans Mattson's recruitment in 1874 of Finns to Manitoba.' In some cases the steps of recruited emigrants were not followed by others. An example of this is found in the Helsinki area. From this area a Finn named Charles Linn, who had migrated to the United States already in the 1830 's, took more than 50 emigrants to Alabama in $1869 .{ }^{8}$ Emigration later from this area to Alabama seems to have been non-existent and emigration from Uusimaa province to North America, excluding perhaps Helsinki, does not appear to have occurred until the 1890's.

Examples of migration traditions created by recruiters are also known outside of Finland, even though migration traditions in general have been researched very little. Migration traditions from the iron industry areas of Sweden to Worcester, Mass., originated when an industrialist from Worcester came to recruit Swedish tradesmen for his enterprise. ${ }^{9}$

Emigrant recruiters were, thus, one source of migration traditions. Sailors may also have had some significance as creators of traditions. Since the emigration from the Aland Islands and the islands and coast of southwest Finland was directed expressly to New York, it seems undeniable in this case that sailors had a particular influence. A large part of the population of this area was concerned with navigation and the number of sailors may have been quite con- 
siderable. Some sailors leaving southwest Finland are known to have become domiciled in New York already in the mid-nineteenth century. ${ }^{10}$ When emigration received the characteristic of a mass phenomenon in the 1880 's in the Aland Islands and a little later in coastal parishes, it was thus natural to expect emigration to be directed to New York.

Thus in some cases a migration tradition was born from the activities of emigrant recruiters and in others from the connections mediated by sailors. We also know that emigration from many localities began when emigrants departed from one locality under the influence of emigrants from neighbouring localities. Emigrants left together with relatives and friends living in neighbouring villages and communes. In this way, emigration spread from village to village and commune to commune.

Conditions for the birth of a migration tradition were exceptionally good if the first emigrants from a certain locality happened to arrive at a place in North America where longterm employment suitable for the emigrant was available. As regards Finnish emigration, the first such areas were the mining areas of Michigan where Finns worked from the 1860's on. Even though Finns settled in Minnesota fairly early, Minnesota possessed no true magnetism before the 1880's or 1890's when the mines of northern Minnesota became really important. The earliest Finnish emigration to Minnesota was directed either to Minneapolis or certain small farming areas. These areas seem to have continually attracted emigrants but in comparatively low numbers. In the eastern parts of the United States, Yew York city and certain industrial towns in Massachusetts, particularly Fitchburg and Worcester, were localities whose economic life created conditions for lasting and strong migration traditions. Industrial locations in Pennsylvania, Ohio and Illinois such as Monessen, Ashtabula Harbor and Waukegan have attracted a very considerable portion of the emigrants from some Finnish localities. However, this was not a significant portion of Finland's total emigration. Comparatively weaker migration traditions restricted to smaller areas can be found in Canadian mining and forest industry centers, the mining centers of the mountain states and the fishing centers of the Pacific Coast. ${ }^{11}$

To what extent then did the occupational structure of the departure area affect the choice of area of settlement in the destination area? In Sweden it has been observed that emigrants from agricultural areas have generally settled in the agricultural areas of 
the Mid-West and those from the iron industry centers in the iron industry centers of Massachusetts. ${ }^{12}$ Can comparable observations be made in Finland? $\mathbf{F}$ the destination of the urban and rural emigrants of 1905 are compared, it is observed that there were relatively more urban arrivals among the total Finnish arrivals to New York (City) and Illinois. Of the total Finnish arrivals to New York, $10 \%$ originated from urban centers. New York received 435 emigrants from the urban centers of Finland. This was $19.9 \%$ of the total arrival of Finns in Mew York. Illinois received 47 urban emigrants, which was $15.3 \%$ of the total number of arrivals in Illinois. Of the Finns arriving in Minnesota, 129 or $8.9 \%$ originated from cities, while of those arriving in Michigan, 160 or $5.2 \%$ were of a similar origin. We can be certain of the fact that those departing from urban areas, when compared to those from rural areas, represented a higher level of professional education and more specific craftsmanship. The "natural" choice of area of settlement for these immigrants were the urban areas of New York City and Chicago. The settlement of Finnish urban emigrants especially in New York and Illinois is therefore evidence that the occupational structure of the departure area determined to some extent the settlement areas of the emigrants.

\section{The overlapping of migration traditions}

Over how wide an area does a certain type of migration tradition appear? It seems that quite a large part of Oulu province and certain parts of central and eastern Finland formed an area from which the emigration stream consistently flowed to Michigan. An example from the other extreme is offered by the rather small Peraseinajoki commune. Unlike the emigrants from its neighbouring communes, those from Peraseinajoki settled expressly in New York. The area of appearance of a migration tradition seems thus to have been in some cases very large and in some cases very small.

Soon after emigration had begun, many Finnish localities evidently possessed several migration traditions concurrently. The emigration flow was divided among different localities in transatlantic countries. Thus, for example, emigrants from Kälviä in 1873 went to either Pennsylvania or Ohio and in 1882, to Minnesota, Michigan, Ohio, New York or Oregon. In 1890, the objectives were Michigan, Ohio, New York and Oregon, and in 1905, Minnesota, Michigan, Massachusetts, Wisconsin, Ohio, New York, 


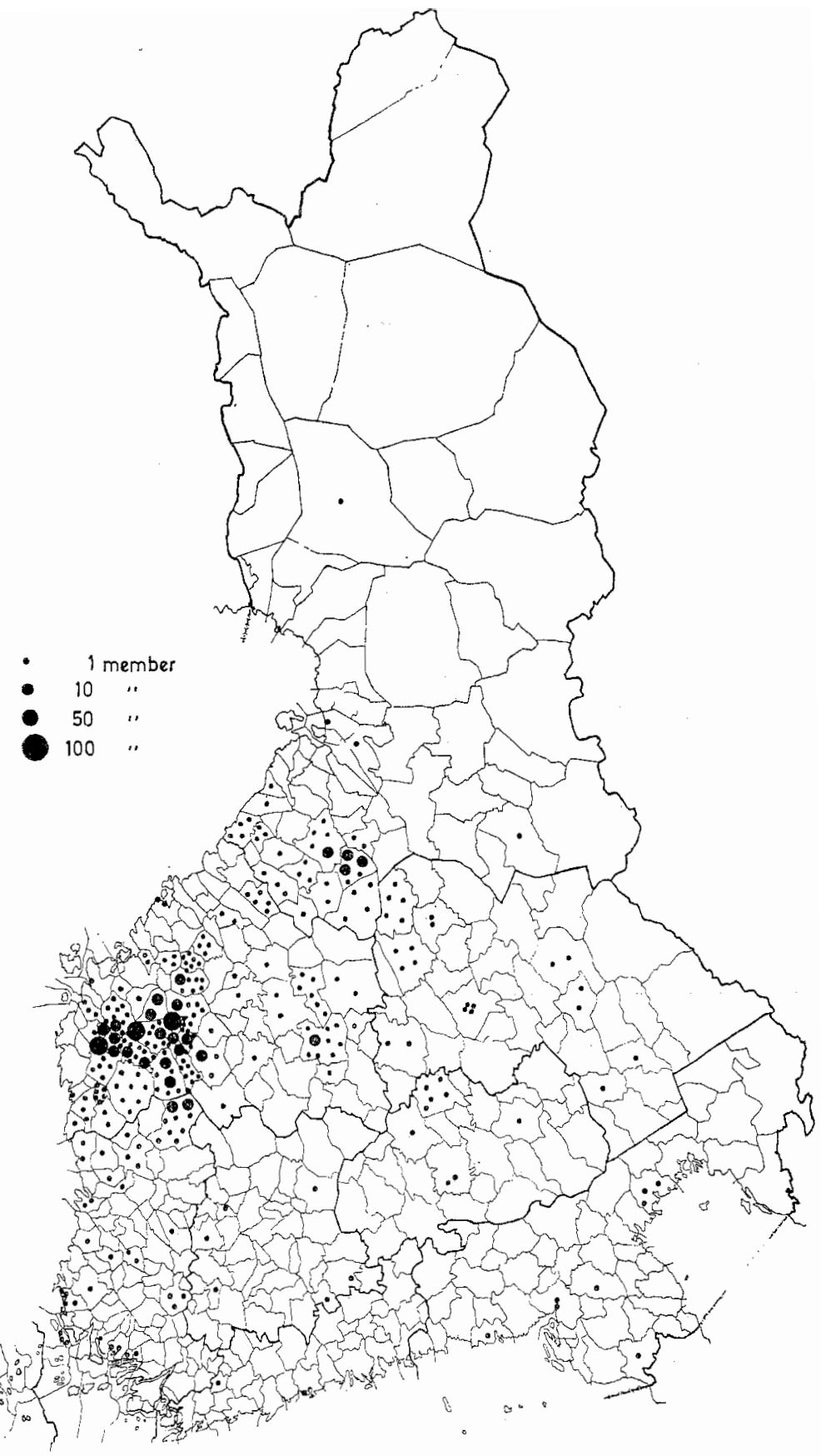

Figure 1. Place of birth for Finnish Evangelical Church members from Worcester, Mass. 


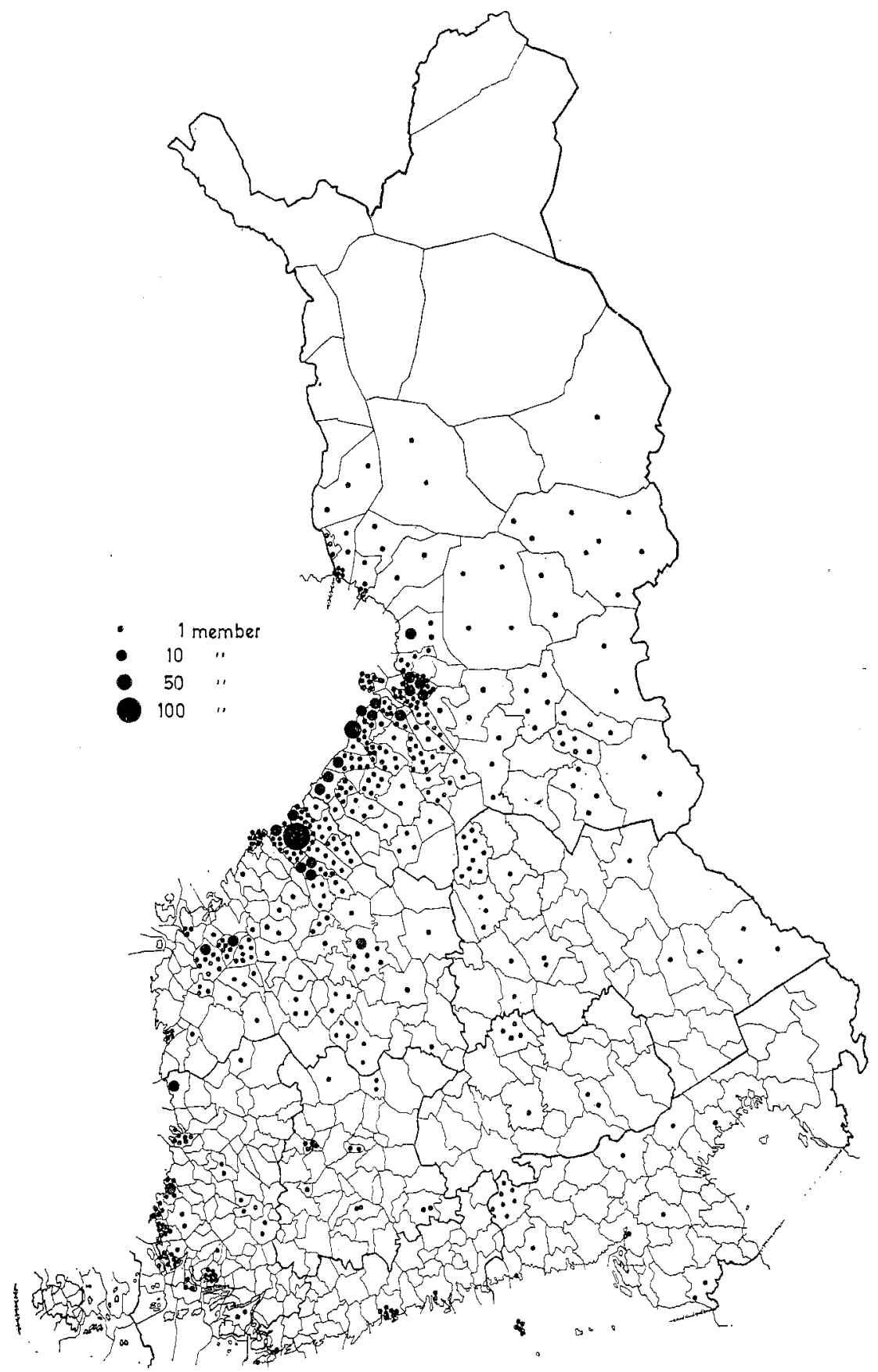

Figure 2. Place of birth for Finnish Evangelical Church members from Astoria, Ore. 
Oregon, Montana, Colorado, Vermont, Maine and Quebec. Emigration from Alaharma was directed to three states in 1882, to eight in 1890 and to nineteen in 1905. Even though the emigration flow became more and more dispersed, Ashtabula Harbor in Ohio and Astoria in Oregon continued to remain very important destinations lor emigrants from Kälviä. Those from Alaharma seem to have had Ishpeming, Mich., and New York City as their constant destinations. It may be said that a departure area with the size of a Finnish commune often possessed 1-2 strong and long-established migration traditions. In addition to these, as the migration phenomenon aged, new traditions were continually born, which - perhaps exceptionally - may have become strong.

How broad then were the areas of origin for Finnish immigrants to such typical immigrant communities as Worcester, Mass., and Astoria, Ore. ? On the basis of the membership records of FinnishAmerican churches it appears that Worcester received immigrants from 107 and Astoria from 137 Finnish communes (See the maps, Figures 1 and 2). About $45 \%$ of the immigrants arriving in Worcester and about $34 \%$ of those arriving in Astoria, however, originated from the five communes with which Worcester and Astoria had the strongest migration traditions.

\section{The duration of migration traditions}

How long did the emigrants from certain small or large areas of departure remain settled in the same area in North America? How long did the migration tradition last between two localities situated on opposite sides of the Atlantic? Even though emigration from Finland began late in comparison with, for example, that from other Nordic countries, it looks as if traditions lasting for 30-40 years can also be found in Finland. For example, the traditions to migrate from Isokyro, Ylistaro and Kalvia to Ohio, and from Kalvia also to Oregon, seem to have lasted 30-40 years.

Since Finnish emigration to the United States ended nearly completely during World War I and was quite small even during the 1920's the migration traditions born during the end of the nineteenth century and the beginning of the twentieth century were broken. The longest had evidently lasted 30-40 years, the shortest only a few years. Migration traditions had probably been broken off already before World War I interrupted the emigration flow. As an example we may mention Orange, Texas. Many 
hundreds of Finns travelled there to work in the forests at the end of the 1880's and in the early 1890's. But by the early twentieth century it was an unknown migration objective among Finns. When the numbers of Finns in some mountain states began to decline already at the beginning of the twentieth century, ${ }^{13}$ it would appear that the particularly strong migration traditions to this area from communes in northern parts of Vaasa province were also broken off.

\section{The importance of migration traditions}

What did a long-lasting migration tradition between a locality in the departure area and one in the area receiving emigrants signify? It is impossible to give a definite answer to this question, but if we consider that emigrants departing from a certain locality arrived in an area in America, or elsewhere, where there was abundant long-term work available, this played its own part in creating the conditions for the expansion of the emigration of the departure area. As time passed the destination area became well known to the population of the departure area and the adventure-seeking characteristic of emigration disappeared. Then again, the breaking off of a migration tradition may have "disturbed" the emigration of the departure area. The emigrant then could not expect to move to the "other home village" in America. Me had to move to a locality about which comparatively little was known and where there were perhaps only a few relatives and friends. This could at least temporarily cause emigration to decline.

\section{NOTES}

1 Recent emigration history research has emphasized the significance of migration traditions. See for example Sten Carlsson, "Chronology and Composition of Swedish Emigration to America", in From Sweden to America. A History of the Migration. Eds. H. Runblom and H. Norman. Uppsala 1976, pp. 138-140; Hans Norman, "Swedes in North America". Op. cit., pp. 255 f.

2 The information on the destinations of emigrants from different localities is based on statistics concerning the emigrants for the years 1873, 1882, 1890 and 1905 prepared at Turku University.

3 The area includes southwest Finland and the Aland Islands such that the most distant communes included are Laitila, Karjala, Kuusjoki, Poytya, Koski Tl., Kiikala, Nummi, Pusula, Pyhajarvi, Vihti and Kirkniemi. 
4 For an account of the earliest Finnish emigration to Canada see Reino Kero, "Emigration from Finland to Canada before the First World War". The Lakehead University Review 1/1976, pp. 7-16.

5 For more on this recruitment activity see Ingrid Semmingsen, Veien mot vest. Utvandringen fra Norge til Amerika 1865-1915. Oslo 1950, pp. 105-107; Lars Ljungmark, For Sale - Minnesota. Organized Promotion of Scandinavian Immigration 1866-1873. Stockholm 1971, pp. 186-189.

6 Kero, op. cit., pp. 9-13.

7 Reino Kero, Migration from Finland to North America in the Years between the United States Civil War and the First World War. Vammala 1974, pp. 166-167.

8 Op. cit. p. 161.

9 Norman, op. cit., p. 255.

10 Salomon Ilmonen, Amerikan Suomalaisten Historiaa I. Hancock, Mich., 1919, pp. $127-148$.

11 The intensity of migration traditions directed to the western parts of the United States are perhaps more difficult to estimate with the help of the statistical material based on passenger lists. For example, comparatively few Finns went to the state of Washington according to passenger lists, but on the basis of the United States population statistics this state appears to be one of the most important as regards Finnish emigration. Washington, like some other western states, must then have received abundant "stage migrants", or emigrants who purchased a ticket to a locality in eastern or central United States but then migrated west fairly soon.

12 Norman, op. cit., pp. 249-252.

13 For example, the number of Finns in Wyoming was, according to the United States population statistics, 1220 in 1900 and 856 in 1920, while the number of Finns in the USA grew from 62641 to 149824 during the same time. 